\title{
TOP-4 SECRETS FOR SCIENCE LITERACY PROMOTION
}

\begin{abstract}
This article informs about new segment of scientific activity, which is developing rapidly through the entire world, namely: science literacy. The results of two international conferences on the subject (Beijing, 2018 and 2019) were presented. Discussions on these conferences gives enough confirmations that science literacy has its own niche (target group, methodology, etc.), which is differ from well-known STEM (science, technology, engineering, mathematics). The main objective of STEM is the selection of talented individuals. The same time certain amount of scientific information is required not only for the mentioned individuals but also for the rest people of our planet. It is impossible to identify correctly what is the percentage of population has interest in specific scientific information. But there are no doubts that all inhabitants of the Earth should have fair information of how science, technology and engineering would change their personal life in the nearest and far future. Climate change is the most evident example. But one also can add artificial intelligence as well as irradiation influence from cell phones on the brain, or shortage of pure water and etc. To cover above demands the specific area of scientific activity should be distinguished. The natural name of this area is science literacy. As the first step of science literacy identification the author gives its own definition of new area of scientific activity. The specific promotion tools for this new area of scientific activity already exist worldwide. They are: popular science books, technical museums and etc. Author analyzed these tools and made the conclusion that for efficient science literacy promotion they should be: a) inexpensive; b) reproducible; c) interesting; d) using modern technologies. The examples, which confirm this conclusion, were listed. The action plan was proposed for more efficient international promotion of science literacy.
\end{abstract}

Keywords: science literacy, STEM (science, technology, engineering, mathematics), Definitions, implementation tools.

\section{INTRODUCTION}

World Science Literacy Conference was held in Beijing in October 2019. It was the second Conference on this issue. Both were organized by China Association for Science and Technology (CAST) [1]. Presented reports and the Round Table discussions showed high ranking of the subject. Moreover, this statement is correct not only for the developing countries, but also for the developed countries, presented by France and Norway. The size of this article doesn't allow to give comprehensive review of all presentations. Thus, we describe only two of them [2].

Prof. Guan Xiaohong from Jiaotong University in his presentation demonstrated very strong links between music and mathematic. Prof. Guan Xiaohong even insisted that music is additional part of mathematic, similar to algebra or geometry. For his idea wider distribution Prof. Guan Xiaohong organized special format of promotion in different region of China: lecture about mathematics as the first part and concert of National Symphony Orchestra as the second part. The concert in such presentation realizes two functions: a) natural one, which is enjoyment from music; b) confirmation of author's scientific results.

Comparison of science literacy (SL) level in different countries of European Union was presented by Dr. Michel Claessens from European Commission (EC). EC funded research for interviewing of large group of people in different countries of European Union. This interview should demonstrate difference in SL level of the different regions. The indicator of SL level is correct meaning of some "scientific words", like "virus". Researchers prepared two-column table with scientific expression in the first column and few explanations in the second one. The only one meaning is correct. Naturally, that more correct answers means higher SL level. Dr. Claessens also presented the next step of this research, which is extension of investigation aria to other countries, including China and the US.

The most important parts of both SL conferences were Round Tables, where the representatives of different countries discussed the opportunity for creation of new institution: World Organization of Science Literacy (WOSL). During the second Round Table in Oct, 2019 representatives of almost twenty countries created Working Group (WG) and started discussion about WOSL Statute preparing. WG members agreed unanimously that the first priority of our job is clear definitions of WOSL objectives.

Being member of above mentioned WG the author considers this paper as preparatory materials for the third round of discussion. 


\section{THE OBJECTIVE OF THIS ARTICLE}

There are a lot of activities worldwide, which are describing modern scientific results in popular format by use "old tools", like journals of popular science or technical museums or "new ones", like YouTube or museum of science. STEM (acronym of Science, Technology, Engineering, Mathematics) appeared recently and it covers probably almost all the world for today. Does mankind need something else?

There are the following objectives of this article: 1) to present author's definition for Science Literacy; 2) to demonstrate that examples of SL activities according to proposed definition already exist worldwide; 3 ) show the examples of success stories of SL promotion.

\section{SL VS STEM/ NICHE FOR SCIENCE LITERACY}

One can find the acronym STEM (Science + + Technology + Engineering + Math) worldwide [3]. The US started the process of STEM creation and it was spread to other world very fast. There are US STEM alliance; STEM - Europe; STEM Ukraine; STEM in many other countries today. Moreover, author met programs with acronyms: STEMM (STEM + Medicine) or STREM (R means religion). But for any acronyms (STEM itself or its derivatives: STEM + medicine; STEM + religion and etc.) it is the tool for selection of talented people. It means that STEM target group is: individuals or small groups of people. Doing research in physics and technology for more than 20 years author totally supports such objective. Moreover, it is very easy to connect STEM objective and UN Strategic Development Goals (SDG) [4].

But let's look on the subject from another side. In case of above definition STEM covers only few percentages of all human beings. All the rest are outside of the process. Author heard many times from different people something similar to the following: "Math (physics, technology) is very complicated for me, let's speak about something else". And such answers were ok until the end of $20^{\text {th }}$ Century. What are the novelties of present days? Compare to the past, science of $21^{\text {st }}$ Century creates challenges for each inhabitant of our Earth almost every day. There are many confirmations of such statement. Here we discuss two examples only.

The first one is the following. The period from the day of invention of something new to its mass production reduced from decades to years or even months. For confirmation of this conclusion one can read about, e.g., Elon Mask space story. Modern communication networks spread information about certain novelty to billions. At least millions would like and have opportunity to buy this specific novelty. As the result the structure of global industry should be changed very fast to satisfy such demands. The first iPhone appeared in June 2007. Only 10 years have passed and smart-phone market increased from zero to $3 \%$ of world GDP. Above is the example of "kind killing" of traditional professions. Artificial Intelligence (Al) will kill them much more toughly. Many professions (including prestigious ones) will disappear in the nearest future with appearance of millions of unemployed people. Unmanned banks, unmanned call centers and etc. will join unmanned production facilities of $20^{\text {th }}$ Century. The army of couriers will be replaced by fleet of drones. Let's forward above forecast, e.g., to the farmer. The majority of farmers worldwide will consider it similar to annoying fly. But, it seems, farmer's reaction will change, in case the description is finished by the question: Can you recommend your profession for your kids or it will disappear soon?

The second example is about renewable energy production and climate change. The share of renewable energy production was negligible in the total balance in 2000. Since those times Germany increased drastically the total power of renewable sources. Today it is bigger in two times compare to the whole electricity production in Ukraine. In other words, Germany has much more active policy for reducing emission of carbon dioxide. Almost every day one can see on TV the demonstrations against climate change. What is the relationship between German energy policy and mentioned demonstration? And how do both events link to the life of ordinary people?

Let's re-formulate above into the question for ordinary people: Can one build house in certain place or this place will be transferred into the desert in the nearest future?

The list of underlined questions can be extended, but even two such examples undoubtedly show the following. Any person, who feels responsibility for his own future and the future of his family, requires skills for SCIENTIFIC FORECAST. And this conclusion is valid for the person of any profession.

The definition of the acronym CTF (Common Training Framework) is the following: it is $\min$ knowledge and min skills necessary to demonstrate enough competence [5]. Similar to CTF, correct SCIENTIFIC FORECAST requires min initial scientific knowledge and min skills for updating of this knowledge during all the life.

Summarizing all above the author suggests the following definition for SL.

Science Literacy is two intersecting sets of tools both with free access, which gives oppor- 
tunity for any individual to make its own forecast of the influence of development of science and technology on his own life. The first set of tools provides this individual by the min level of basic scientific knowledge. And the second one is for the permanent correction the initial package.

Science Literacy can be considered as reinvention of ancient Chinese Compass. Similar to the old device SL has two components: a) basic knowledge (analog is the base of normal compass); b) permanently updated knowledge (similar to freely turning magnetic arrow).

Above definition shows the niche for Science Literacy and clearly separates it from STEM. Science Literacy is the tool for millions of ordinary people in contradiction with STEM, which is for individuals. Moreover such definition automatically approves the list of activities for Science Literacy, most of which was discussed on the Round Table [6]. Such activities should match "mass production" criteria. This subject will be discussed in the next chapter.

\section{EFFICIENT SCIENCE LITERACY PROMOTION}

There are a lot of efficient tools for SL promotion. Author compares the activities in this area in many countries and recognized same/very similar formats in many regions. It was great surprise that enthusiasts invented such (very efficient) formats independently from each other.

Let's list the most important criteria for SL promotion. Efficient tools should be:

4.1) inexpensive;

4.2) reproducible;

4.3) interesting;

4.4) using modern technologies.

Below the some concrete cases will be described. The description will be answer on the question: how does specific case match the above criteria?

Before analyzing the specific technical cases, the general idea will be illustrated by the case from "ordinary life". Author had seen the group of dancing people in the park in Beijing (China) in Oct 2018. He found absolutely same case on the distance of $8,000 \mathrm{~km}$ from the original place, while returned to Kyiv (Ukraine). These dancing have no relation to SL, but they are excellent illustration of the efficiency of above mentioned criteria, because they are totally in harmony with them:

- the cost is very low, because space is free. The only one restriction is rain/snow;

- reproducibility is evident;

- organizer can selected the list of melodies, which are interesting for the concrete group of people;
- music was produced by Instrument until the mid of 20th Century. Next "generator" was tape recorder. Today each participant can bring his lovely melody on his cell phone. The only one technical unit, which joins the group is sound amplifier.

The same analysis can be applied to the technical cases.

The first example is technical museums.

There are two types of such museums. The first type is traditional one, which has huge space, very expensive exhibits and funding from the government. Author visited such museums in Kyiv, in Zagreb, in Warsaw. These museums totally ignore above criteria and the result is evident: there are few visitors per day only.

Modern museums of science saved only word "museum" in their name, but totally changed the content. Author visited such museums in Warsaw, Kyiv, Lisbon, Beijing and other cities. The whole space in these museums is the place for scientific games. Visitors can learn the structure of Solar system, launch the model of rocket, create bubbles, which are larger than height of human being, etc. This case satisfies almost all criteria, except low cost. And the result is very impressive. Each museum is full of visitors during all the day.

The second example is "zero-cost" construction kit.

One can buy different construction kits in specialized stores. It can be set for young chemists, young physicists, Lego, etc. The common feature of these kits is their price, which starts from $\$ 50$. The same time each family has very inexpensive "store" for initiation of engineering thinking of their kids. Probably each family has box(es) with useless things. Somebody even has the garage, which is full of such boxes. Our colleagues from Kyiv technical center for youth [7] organize Pan-Ukrainian Young Engineering competition annually. The task for each young team is to design and to create the working model by use the box with useless things. The last time future engineers created the model of cranes.

The last example of efficient SL promotion is books for science and technique popularization. It is evident that books match the first two criteria automatically. To be interesting the modern trends should be used, like clip thinking. And the most advanced books are using e-component, namely connection with e-storage with additional information (tests, historical stories, presentations for teachers, etc.).

As one can see, Science Literacy already has efficient tools for its promotion. The nearest task is coordination efforts of enthusiasts from different countries. 


\section{INSTEAD OF CONCLUSIONS: PROPOSED NEXT STEPS}

1. Present situation for SL is not very good. The only one institution - CAST — is promoting this idea officially. There are a lot of competitors, like STEM, in this segment. International support of science literacy as separate type of activity is slow. Really brilliant idea can die without changing the strategy. The same time SL Round Table 2019 found the exit for surviving: immediate and sound international action(s) under the umbrella of Science Literacy logo.

2. The best first international action is web-site creation. Initially such web-site can be very simple: a) It should contain at least three boxes for three different countries; b) each box should contain up to 10 short descriptions about 10 different institutions related to SL; c) the umbrella is general description about SL with invitation for cooperation.

3. Creation of World Organization for Science Literacy is braking because of contradiction between ambitious objective and limited resources. It seems that much more realistic project is creation temporary institution with the name: International
Laboratory for Science Literacy. This temporary organization should demonstrate the real importance of SL for world community. And it can be transformed into World Organization for Science Literacy on the next stage.

\section{REFERENCES}

1. Web-site of China Association for Science and Technology. Retrieved from: www.cast.org.cn.

2. Program and abstracts of the World Conference on Science Literacy (2019). Beijing, China, October. $16-17,100 \mathrm{p}$.

3. Web-site of the US Department of Education. Retrieved from: https://www.ed.gov/stem.

4. UN 17 Sustainable Development Goals. Retrieved from: https://sustainabledevelopment. un.org/?menu=1300.

5. Web-site of European Associations: FEANI and EAHP. Retrieved from: https://www.feani.org/, https:// www.eahp.eu/hp-practice/hospital-pharmacy/ common-training-framework-0.

6. Program and abstracts of the Round Table on the World Conference on Science Literacy (2019). Beijing, China, October. 16-17, 49 p.

7. Web-site of the Center of Scientific and Technical Creativity of the Youth Sphere. Retrieved from: https:// www.ed.gov/stem.

М.М. КІРюХІн, канд. фіз.-мат. наук, с.н.с.

\section{ТОП-4 ТАЕМНИЦІ ДЛЯ ПРОСУВАННЯ НАУКОВОЇ ГРАМОТНОСТІ}

Резюме. У статті наведено інформацію про новий сегмент наукової діяльності, який швидко розвивається в усьому світі та має умовну назву - наукова грамотність. Для підтвердження цієї думки наведено приклади 3 двох міжнародних конференцій, які були присвячені вказаному питанню (Пекін, 2018 та 2019 роки). Дискусії на зазначених конференціях надають достатньо підтверджень того, що наукова грамотність може мати власну нішу (цільова група, методологія тощо), яка відрізняється від добре відомого STEM (наука, технологія, інженерія, математика). Головне завдання STEM - це відбір талановитих людей. Водночас певна кількість наукової інформації потрібна не лише вищезгаданим талантам, а й іншим людям нашої планети. Неможливо точно визначити, який саме відсоток населення цікавиться спеціальною науковою інформацією. Однак не має жодних сумнівів у тому, що всі жителі Землі повинні мати достовірну інформацію про те, яким чином наука, техніка та інженерія змінять їхнє особисте життя в найближчому та віддаленому майбутньому. Зміна клімату $є$ найбільш яскравим прикладом. До цього можна додати штучний інтелект, вплив випромінювання від мобільних телефонів на мозок, нестачу питної води тощо. Для задоволення інтересів людства, які вказані вище, потрібно сформувати нову сферу наукової діяльності. Природна назва для цієї сфери - наукова грамотність. Першим кроком ідентифікації наукової грамотності автор пропонує для неї власну дефініцію. Спеціальні інструменти для просування в цій сфері наукової діяльності вже існують в усьому світі. Це науково-популярні книги, технічні музеї тощо. Автор проаналізував ці інструменти та дійшов висновку стосовно того, що для ефективного просування наукової грамотності вони мають бути: а) недорогими; б) такими, що відтворюються; в) викликати інтерес; г) використовувати сучасні технології. У статті наведено приклади, які підтверджують цей висновок, а також запропоновано план дій для більш ефективного міжнародного просування наукової грамотності.

Ключові слова: наукова грамотність, STEM (наука, технології, інжиніринг, математика), визначення понять, механізми впровадження.

Н.М. КИРюХин, канд. физ.-мат. наук, С.н.с.

\section{ТОП-4 СЕКРЕТА ДЛЯ ПРОДВИЖЕНИЯ НАУЧНОЙ ГРАМОТНОСТИ}

Резюме. В статье приведена информация о новом сегменте научной деятельности, который стремительно развивается во всем мире и носит условное название - научная грамотность. Для подтверждения приведены примеры из двух международных конференций по этому вопросу (Пекин, 2018 и 2019 годы). Дискуссии на этих конференциях дают достаточно подтверждений относительно того, что научная грамотность может иметь свою нишу (целевая группа, методология и т. д.), которая отличается от хорошо известного STEM (наука, технология, инженерия, математика). Основная задача STEM - отбор талантливых людей. В то же время, некоторое количество научной информации требуется не только упомянутым талантам, но и остальным людям нашей планеты. Невозможно правильно определить, какой процент населения имеет интерес к конкретной научной информации. Но нет никаких сомнений в том, что все жители Земли должны располагать 
достоверной информацией о том, как наука, техника и инженерия изменят их личную жизнь в ближайшем и отдаленном будущем. Изменение климата является наиболее ярким примером, но также можно добавить искусственный интеллект, влияние облучения от сотовых телефонов на мозг, нехватку чистой воды и т. д. Чтобы удовлетворить вышеуказанные запросы, следует сформировать новую область научной деятельности. Естественное название этой области - научная грамотность. В качестве первого шага идентификации научной грамотности автор предлагает для нее собственное определение. Специальные инструменты продвижения для этой области научной деятельности уже существуют во всем мире. Это научно-популярные книги, технические музеи и т. д. Автор проанализировал эти инструменты и сделал вывод, что для эффективного продвижения научной грамотности они должны быть: а) недорогими; б) воспроизводимыми; в) интересными; г) использовать современные технологии. В статье приведены примеры, подтверждающие этот вывод, а также предложен план действий для более эффективного международного распространения научной грамотности. Ключевые слова: научная грамотность, STEM (наука, технологии, инжиниринг, математика), определение понятий, механизмы внедрения.

\section{INFORMATION ABOUT THE AUTHOR}

Kiryukhin M.M. - PhD in Physics and Mathematics, Senior Researcher, President of Union of scientific and engineering societies of Ukraine, 21 Sichovykh Striltsiv Str., Kyiv, Ukraine, 04050; +38 (044) 272-42-85; info@snio.org. ua; ORCID: 0000-0001-6017-4043

\section{ІНФОРМАЦІЯ ПРО АВТОРА}

Кірюхін Микола Михайлович - канд. фіз.-мат. наук, С.н.с., президент Спілки наукових та інженерних об'єднань України, вул. Січових Стрільців, 21, м. Київ, Україна, 04050; +38 (044) 272-42-85; info@snio.org.ua; ORCID: 00000001-6017-4043

\section{ИНФОРМАЦИЯ ОБ АВТОРЕ}

Кирюхин Н.М. - канд. физ.-мат. наук, с.н.с., президент Союза научных и инженерных объединений Украины, ул. Сечевых Стрельцов, 21, г. Киев, Украина, 04050; +38 (044) 272-42-85; info@snio.org.ua; ORCID: 0000-00016017-4043

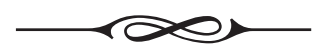

\section{ДО УВАГИ НАУКОВЦІВ!}

Комплексне інформаційне обслуговування - це створені в УкрIHTEI періодичні інформаційні матеріали з найактуальніших питань наукового, науково-технічного та інноваційного розвитку і трансферу технологій щомісячно в on-line режимі впродовж року.

Пропонуємо вам інформаційні пакети:

- “Наука, технології, інновації - 6 видань щомісячно;

• “Комплексний інформаційний пакет” - 9 видань щомісячно.

Детальніше на сайті УкрIHTEl: www.ukrintei.ua

\section{КОНТАКТИ:}

тел. (044) 521-00-39, 521-09-48, e-mail: uintei.ua@gmail.com, uintei.info@gmail.com, sale@uintei.kiev.ua 